CASE STUDY

\title{
Building Souls and CVs in a Student-Run Podcasting Course
}

Emily Liatsis, Film and Media Studies, Bishop's University, Canada

Ethan Pohl, Sociology, Bishop's University, Canada

*Jessica Riddell, Stephen A. Jarislowsky Chair of Undergraduate Teaching Excellence, Bishop's University, Canada

Contact: jriddell@ubishops.ca

ABSTRACT

This case study discusses an experiential learning course comprising a 12-episode podcast series dedicated to transformative learning in higher education. The threecredit course, which was designed by two student leaders (station managers at the university radio station) in collaboration with a faculty collaborator, was informed by the 10 design principles of authentic learning. The central premise of the podcast series hinged on two key questions: What are the ideal conditions where students build their souls as they build their CVs?; What are the conditions for transformative learning whereby students reflect on their learning experience as collaborators with their professors and with one another? The case study offers recommendations to students, faculty, and educational developers who might integrate this model into their own practices.

\section{KEYWORDS}

authentic learning, podcasts, innovative pedagogy, transformative learning, student engagement, experiential learning, student partnerships

When do students realize they are building their souls in addition to building their CVs? This question inspired an experiential learning course where students produced a podcast series with 12 episodes dedicated to exploring the conditions that enhance transformative learning in higher education. The three-credit course was designed and implemented by two student leaders (station managers at the student-run university radio station, called Toast Radio) in collaboration with a faculty member at Bishop's University, a small, primarily undergraduate institution with a focus on delivering a liberal education. The course organizers used 10 design principles of authentic learning (Herrington, Oliver, \& Reeves, 2003) in order to 
build a podcast series that took its central premise from the following questions: What are the ideal conditions where students build their souls as they build their CVs?; What are the conditions for transformative learning with a particular focus on how students reflect on their learning experience as collaborators with their professors and with one another?

The three-credit course was offered over a 12-week winter semester and had an enrolment of 15 undergraduate students from a diverse range of programs, including English, film and media studies, creative writing, journalism, education, sociology, sports studies, and business. All the students enrolled in the course were in their second year or higher, and $20 \%$ were international exchange students (from the USA and the UK). Three teams of five students each identified four professors who were particularly effective in facilitating conditions of transformative learning by soliciting feedback via a student survey, interviewing their peers, and examining professors' engagement as educational leaders (from a pool of 125 full-time, tenure-stream faculty and 60 contract faculty). The professors' research and teaching interests were noted, and students who had experience with these professors as educational leaders and transformative educators were interviewed for their perspectives. From this research, the teams designed questions, recorded interviews, and edited each podcast for a high-quality final product. Students in the course were also involved in designing logos, branding the podcast series, developing a communication strategy to launch the podcast, and organizing a public podcast launch.

\section{PROJECT OVERVIEW}

\section{Context and rationale}

The initial idea for a student-led podcast series emerged from an informal conversation among students about adding new programming to Toast Radio. With so many radio stations going off air, on to XM or online, broadcast journalism is changing rapidly, the station managers recognized the importance of growing Toast Radio in fresh and accessible ways.

The design of a three-credit podcast course was made possible through a series of conditions within the institutional context: namely, a primarily undergraduate, liberal education institution with rich extracurricular programming, an abundance of academic and experiential learning activities, supportive faculty, and high levels of faculty-student interactions. ${ }^{1}$ The student leaders identified a full-time, tenured professor to act as faculty champion. This professor was selected for her reputation as a collaborator who was open to students with creative and divergent ideas and had experience creating authentic learning scenarios for undergraduate students.

The faculty champion and the two student leaders designed a three-credit broadcast journalism course for the winter term. Each assumed roles based on their expertise and interests. The faculty champion assumed the role as the course facilitator and was responsible for course administration, timetable, and syllabus design. One student leader acted as student coordinator, conducting extensive research into podcasts, and leading class modules on interviewing techniques and how to research interviewees. The second student leader took on the role as technical director, responsible for technical aspects of the course such as researching broadcasting equipment, equipment training, and troubleshooting. The three collaborators met extensively in advance of the course to design the syllabus based on the 
principles of authentic learning, develop reflective exercises and resources to build effective group dynamics, and ensure that assessment aligned with the course competencies.

\section{Students as Partners: Literature overview}

Since this was an entirely new model of course design for the team members, the course facilitator, student coordinator, and technical director reviewed the literature on the students-as-partners (SaP) learning model. We were particularly interested in challenging the students-as-consumers model in favour of a more holistic and collaborative model that highlights the shared responsibility of students and teachers in the learning endeavour (Mathews et al., 2018). SaP repositions the traditional hierarchy of teacher-learner, where student contribution is not only valued but implemented (Mathews et al., 2018; MercerMapstone et al., 2017). Student partnerships increase levels of student engagement, provide students with an increased sense of leadership and a responsibility for one's learning, and increase motivation around the learning process for both students and instructors (MercerMapstone et al., 2017; Cook-Sather \& Abbot, 2016; Healey, Flint, \& Harrington, 2014). Furthermore, research on student-staff partnerships highlights personal development for both students and staff, in concert with an enhancement of the learning climate (Curran, 2017). While a large portion of SaP literature reports positive outcomes, the positive reporting bias evident in academic research must be noted (Mercer-Mapstone et al., 2017). The "repositioning of the roles of students and staff in the learning endeavour" differentiates students-as-partners from simple student engagement or student involvement in initiatives (Mercer-Mapstone et al., 2017). Changing the traditional professor-student, assessor-assessed, teacher-learner dichotomy was an integral part of the course design and implementation. What is so unusual about this course was that students were involved from the outset in its creation and played a central role in the design of the syllabus and assessment methods, as well as the facilitation of modules, podcast pitches, and critical reflection assignments.

Student coordinators also participated in the course as students, which reinforced efforts to upend traditional hierarchies in the classroom. The role and power of professor was not simply shifted to students; rather, student leaders facilitated discussions while still participating fully in the learning experience. This case study therefore differs significantly from other students-as-partners models where students provide pedagogical feedback or design and influence course modules after participating in a course (Healey, Flint, \& Harrington, 2014; Marie \& McGowan, 2017). While several SaP initiatives involve students in the creation of course modules or curriculum design, little attention is paid to the outcomes of students participating in and influencing the modules during and after their creation (Lubicz-Nawrocka, 2018; Marie \& McGowan, 2017; Bergmark \& Westman, 2016).

\section{Design considerations}

Authentic learning is an active learning model that has a significant impact on student learning outcomes (Diamond, Middleton, \& Mather, 2011; Lombardi, 2007; Rule, 2006; Newmann, Marks, \& Gamoran, 1996; Bransford, Vye, Kinzer, \& Risko, 1990). Authentic learning environments "help students become actively engaged in the learning process, rather than passive receptors of content knowledge" (Burke, 2009, p. 10). Herrington, Oliver, and Reeves (2003) assert that authentic learning "encourages and supports learners in their development 
of skills in self-regulation and self-learning" (p. 68). Furthermore, authentic learning can enhance the transfer of deep and lifelong learning (Herrington, Oliver, \& Reeves, 2003; Barab \& Landa, 1997). Reeves, Herrington, and Oliver (2002) outline 10 design principles that can generate authentic learning environments in "Authentic Activities and Online Learning." The coursework in ENG 454: Broadcast Journalism was formulated around authentic learning design principles (Herrington, Oliver, \& Reeves, 2003) and augmented with Marie and McGowan's (2017) conclusions on partnership values and sustainability. From the outset, the students and the course facilitator were committed to the idea of a collaborative partnership. In the first class, students reflected on their individual strengths and weaknesses using writing prompts (e.g., "write a reflection on your individual strengths, areas that are challenging, and areas you would like to develop over the course of your project"). Students were then organized into groups based on their self-identified skill sets: for example, students who identified strengths in editing and weaknesses in organization and time management were matched with students who were not as skilled in editing but self-identified as having excellent time management skills. Groups benefited from interdisciplinary perspectives as every effort was made to place students from different faculties in each group.

The podcast series was designed around the following guiding vision, as stated in the course syllabus:

At Bishop's University, we strive to build souls as much as we build CVs. We showcase transformative learning via faculty-student partnerships, both in the classroom and beyond. This podcast series will ask: What transforms us? What builds our souls? What do the authentic faculty-student collaborations have in common? Why does this model flourish at Bishop's? We take as our central premise that the best professors are the ones who model humility, failure, resilience, and-ultimately-their own humanity.

Podcast teams were encouraged to explore their own interpretation of this guiding vision to design, research, record, and publish their podcasts. To produce podcasts that adhered to the guiding vision, each group had to collaborate closely. This sustained investigation that lasted 12 weeks required students to engage with multiple sources and perspectives in order to compile the amount of research on the interviewee (e.g., their field of study, teaching interests, engagement in scholarly activities outside the classroom). Students were asked to reflect on the process of podcast creation every three weeks in both team and self-reflection journals. Each group developed their own interpretation of the guiding vision using a unique podcast style that reflected their group dynamic and work ethos. Despite these differences in final products, each podcast met the guidelines established by the class and successfully achieved course objectives.

One of the main concerns with group work is accountability and self-regulation (Karau \& Williams, 1993; Latané, Harkins, \& Williams, 1979). Social loafing "is the reduction in motivation and effort when individuals work collectively compared with when they work individually or coactively" (Karau \& Williams, 1993, p. 681). To combat these potential challenges, the first two weeks of course time devoted significant class discussion to group dynamics, self-regulation, and course expectations. Furthermore, all students signed commitment contracts, with each group developing its own guidelines and expectations-thus establishing a shared sense of 
accountability. Groups met once per week outside of the classroom and recording sessions to discuss group and individual goals, assign tasks, and plan, research, and formulate interview questions. We also had a conflict management plan in place: if there was a disagreement or a group member felt that they were not being treated fairly, the group discussed the commitment contract and conflicts were resolved quickly and collegially.

Drawing on literature that highlights the importance of involving students in assessment to enhance learning, the assessment system for the course used peer review and formative feedback as the primary modes of assessment (Fluckiger et al., 2010; Giles et al., 2004). Students were asked to reflect on the following example questions: How do we assess podcasts using a framework comparable to the industry standard? How do we accommodate students who may be uncomfortable with one or more aspects of the course requirements?

Students assessed themselves and their peers on course involvement. The self and team assessments encompassed both quantitative questions that measured students' perceptions of their learning experience and qualitative reflection. Creating an assessment model to evaluate the podcasts was more challenging because the rubric had to measure academic rigour and industry relevance while recognizing that maximizing student accomplishment is best done through focusing on learning rather than assigning grades (Fluckiger et al., 2010). The rubric was tested extensively among the three course facilitators as well as among the students. The final rubric identified several areas to assess, including content, broadcasting/interviewing, editing. Each student assessed the podcasts produced by the other teams and provided both a numerical grade and written feedback. Recognizing that feedback is ineffective if given solely at the end of the learning cycle, students submitted two podcasts in February and two podcasts in March, with feedback provided promptly by the other students on how to improve (Fluckiger et al., 2010). Students were encouraged to ask questions and receive help. The end result of this formative assessment process was a stronger product than if there had been with only a summative assessment. Students were then given time to refine their four podcasts and submit finished ones to Youtube.

\section{Critical reflection}

Learning in university is often framed as preparation for employment and the job market post-graduation. However, the reverse is less likely in liberal education universities and it is rare that professional industries inform classroom learning outside of trade degrees and vocational schools. The technical director (a third-year undergraduate student) had experience in the professional radio industry and this in-house expertise added a dimension of practicality and real-world relevance with industry-standard quality assessment.

The student coordinator occupied both student and lecturer roles. As learner-teacher, the student coordinator tried to create a power dynamic that was based on mutual respect, equality, and collegiality rather than hierarchy. She accomplished this by positioning herself as a collaborator who was learning alongside her classmates, not as an expert in podcast design. The student coordinator reflects,

By occupying this position [...] I developed insight into the role of the professor in the classroom and the amount of work outside of the classroom that goes into planning a lecture, encouraging participation, and keeping the class on track. This has deepened 
my perspective on the role of professor and the lengths they go to maintain an engaged class, and to ensure that the students have all of the tools that they need in order to succeed.

Every effort was made to be inclusive, collegial, and adaptive to the needs of the group (Corbett, 1980).

The course facilitator worked with the student leaders as a resource for pedagogical design, as logistical support when challenges during course implementation presented themselves, and as a mentor for bolstering students' confidence and offering encouragement and strategies for managing inevitable obstacles (e.g., scheduling interviews, coordinating deadlines, technical issues, brainstorming interview questions). As part of the course agenda was to make student partnerships more visible on campus, the course facilitator booked course meetings and sessions in the large university boardroom usually occupied by the Senate, Board of Governors, and Faculty Council. By working in spaces usually occupied by administration, students were encouraged to think of themselves as equal partners in the creation and maintenance of an institution of higher learning.

We encountered a number of challenges. Student aptitude varied, which was reflected in inconsistent sound quality and podcast editing. In terms of student engagement, students did not always adhere to deadlines (e.g., providing peer feedback, submitting podcasts on time). Despite (or because of) the fact that we dispensed with the role of the professor as an authority figure who determines late assignment consequences, all podcasts were produced by the end of term and launched successfully. According to the qualitative data-peer and team assessments and end-of-term group reflections-the strengths of the course were the experiential learning design and inquiry-based learning built into the authentic learning principles. The course encouraged sustained collaboration in meaningful ways to produce a final product in collaboration with team members while still promoting individual accountability and avoiding "social loafing." When asked to reflect on their experience in their final reports, students felt they were in control of their learning - they were active and engaged as opposed to having "a passive listening role through lecture-based courses." Students also felt that the course design successfully simulated a real-world working environment. To create successful podcasts, the students expressed the need to collaborate with kindness and diplomacy, participate in meaningful discussions, and adopt and implement different viewpoints in order to complete their tasks. By participating in this course, students not only learned the basics of podcast production but also how to be resilient in the face of failure. The self-assessment process encouraged students to talk about their failures, receive positive and productive feedback, reassess their methodology, and then refine their podcasts before final submission.

To conclude, four key factors were necessary to turn this from an idea into an academically rigorous credit course:

1) Purpose: We believed that this was an important intervention to ensure the sustainability and relevance of the student-run radio station.

2) Passion: We were committed enough to devote countless hours to this project and students were inspired to engage in this project in meaningful ways.

3) Mentorship: A faculty sponsor, mentor, and champion were essential in the process to design and implement an academically rigorous course. 
4) Empowerment: It is essential that a liberal education institution encourage and empower students to go above and beyond in their learning in order to cultivate change in their environments.

NOTES

${ }^{1}$ Bishop's University has traditionally and consistently ranked high in external measurements of teaching excellence. For example, in 2016, Maclean's ranked the university 1st for "quality of instructors," "residence living," and "student satisfaction;" 2nd for "professors who know your name" and "extracurricular activities;" and 5th for "obtaining employment skills" (Schwartz, 2016). The Globe and Mail's (2016) university report card ranked the university above average for "overall student experience." The Huffington Post (2017) ranked the university 1st in the country for "sports and recreation" and "extracurricular activities" and 2nd in the country for "best food." The National Survey on Student Engagement (NSSSE) in 2015 placed the university in the top $10 \%$ of universities in North America in the following categories: collaborative learning, higher order learning, student-faculty interaction, supportive environment, and quality of interaction.

\section{NOTES ON CONTRIBUTORS}

Emily Liatsis recently graduated from Bishop's University with a BA in English and a concentration in film and media studies as well as a minor in theatre. While at Bishop's, she was the station manager for the university's Toast Radio. She is now pursuing a career in creative and communication forms that engage with the vibrant arts culture in Toronto.

Ethan Pohl is a fourth-year BA Honours student at Bishop's University, studying sociology with a concentration in criminology, law, and social policy and a minor in political studies. He is the station manager for Toast Radio and has experience working in the professional radio industry in Boston.

Jessica Riddell is the inaugural Stephen A. Jarislowsky Chair of Undergraduate Teaching Excellence at Bishop's University and a professor of Shakespeare in the English department. She is a 3M National Teaching Fellow (2015) and the Executive Director of the Maple League of Universities, a consortium of universities that focuses on enhancing undergraduate education through a liberal education lens.

\section{REFERENCES}

Bergmark, U., \& Westman, S. (2016). Co-creating curriculum in higher education: Promoting democratic values and a multidimensional view on learning. International Journal for Academic Development, 21(1), 28-40. http://dx.doi.org/10.1080/1360144X.2015.1120734

Barab, S. A., \& Landa, A. (1997). Designing effective interdisciplinary anchors. Educational Leadership, 54, 52-55. 
Barab, S. A., Squire, K. D., \& Dueber, W. (2000). A co-evolutionary model for supporting the emergence of authenticity. Educational Technology Research and Development, 48(2), 37-62.

Bottomley, A. J. (2015) Podcasting: A decade in the life of a "new" audio medium: Introduction. Journal of Radio \& Audio Media, 22(2), 164-169.

Bransford, J. D., Vye, N., Kinzer, C., \& Risko, V. (1990). Teaching thinking and content knowledge: Toward an integrated approach. In B. F. Jones \& L. Idol (Eds.), Dimensions of thinking and cognitive instruction (pp. 381-413). Hillsdale, NJ: Lawrence Erlbaum.

Bransford, J. D., Brown, A. L., \& Cocking, R. R. (Eds.). (1999). How people learn: Brain, mind, experience, and school. Washington, DC: National Academy Press.

Burke, K. (2009). How to assess authentic learning (5th ed.). London, UK: SAGE Ltd.

Cook-Sather, A., \& Abbot, S. (2016). Translating partnerships: How faculty-student collaboration in explorations of teaching and learning can transform perceptions, terms, and selves. Teaching \& Learning Inquiry, 4(2).

Corbett, B. E. (1980). A garden of children (1st ed.). Mississauga, ON: Froebel Foundation.

Curran, R. (2017). Student as partners-good for students, good for staff: A study on the impact of partnership working on how this translates to improved student-staff engagement. International Journal for Students as Partners, 1(2).

Diamond, S., Middleton, A., \& Mather, R. (2011). A cross-faculty simulation model for authentic learning. Innovations in Education \& Teaching International, 48(1), 25-35. http://dx.doi.org/10.1080/14703297.2010.518423

Edison Research. (2014, September 11). Why podcasting is bigger than you think [blog post]. Retrieved from http://www.edisonresearch.com/podcasting-bigger-think/

Fluckiger, J., Vigil, Y., Pasco, R., \& Danielson, K. (2010). Formative feedback: Involving students as partners in assessment to enhance learning. College Teaching, 58, 136-140.

Giles, A., Martin, S. C., Bryce, D., \& Hendry, G. D. (2004). Students as partners in evaluation: Student and teacher perspectives. Assessment \& Evaluation in Higher Education, 29(6), 681-685.

Healey, M., Flint, A., \& Harrington, K. (2014). Engagement through partnership: Students as partners in learning and teaching in higher education. York, UK: Higher Education Academy. Retrieved from https://www.heacademy.ac.uk/system/files/resources/engagement through partnersh ip.pdf

Herrington, A., \& Herrington J. (Eds.). (2006). Authentic learning environments in higher education. Hershey, PA: Information Science Publishing.

Herrington, A., \& Herrington, J. (2007). What is an authentic learning environment? In L. A. Tomei (Ed.), Online and distance learning: Concepts, methodologies, tools, and applications (Vol. 1, pp. 68-76). Hershey, PA: Information Science Reference.

Herrington, J., \& Oliver, R. (2000). An instructional design framework for authentic learning environments. Educational Technology Research and Development, 48(3), 23-48. http://dx.doi.org/10.1007/BF02319856

Herrington, J., Oliver, R., \& Reeves, T. C. (2003). Patterns of engagement in authentic online learning environments. Australian Journal of Educational Technology, 19(1), 59-71. http://dx.doi.org/10.14742/ajet.1701 
Herrington, J., Reeves, T. C., \& Oliver, R. (2007). Immersive learning technologies: Realism and online authentic learning. Journal of Computing in Higher Education, 19(1), 80-99. http://dx.doi.org/10.1007/BF03033421

Herrington, J., Reeves, T. C., \& Oliver, R. (2010). A guide to authentic e-learning. London, UK: Routledge.

Reeves, T. C., Herrington, J., \& Oliver, R. (2002). Authentic activities and online learning. Paper presented at the 2002 Annual International Conference of the Higher Education Research and Development Society of Australasia (HERDSA), Perth, Western Australia.

Herrington, J., Reeves, T. C., \& Oliver, R. (2014). Authentic learning environments. Handbook of Research on Educational Communications and Technology, 401-412. http://dx.doi.org/10.1007/978-1-4614-3185-5 32

Herrington, J., Reeves, T. C., Oliver, R., \& Woo, Y. (2004). Designing authentic activities in webbased courses. Journal of Computing in Higher Education, 16(1), 3-29. http://dx.doi.org/10.1007/BF02960280

Kaeppel, K., \& Bjorngard-Basayne, E. (2017, May 30). The pedagogy of podcasts [blog post]. Retrieved from https://gcci.uconn.edu/2018/05/30/the-pedagogy-of-podcasts

Karau, S. J., \& Williams, K. D. (1993). Social loafing: A meta-analytic review and theoretical integration. Journal of Personality and Social Psychology, 65(4), 681-706.

Latané, B., Harkins, S., \& Williams, K. D. (1979). Many hands make light the work: The causes and consequences of social loafing. Journal of Personality and Social Psychology, 37(6), 822-832.

Lombardi, M. M. (2007). Authentic learning for the 21st century: An overview. ELI Report 1. Boulder, CO: EDUCAUSE Learning Initiative.

Lombardi, M. M. (2007). Making the grade: The role of assessment in authentic learning. ELI Paper, 1. Boulder, CO: EDUCAUSE Learning Initiative.

Lombardi, M. M., \& Oblinger, D. (2007). Approaches that work: How authentic learning is transforming higher education. ELI Report 5. Boulder, CO: EDUCAUSE Learning Initiative.

Lubicz-Nawrocka, T. (2018). Students as partners in learning and teaching: The benefits of cocreation of the curriculum. International Journal for Students as Partners, 2(1), 47-63.

Matthews, K. E., Dwyer, A., Hine, L., \& Turner, J. (2018). Conceptions of students as partners. Higher Education, 1-15. http://dx.doi.org/10.1007/s10734-018-0257-y

Marie, J., \& McGowan, S. (2017). Moving towards sustainable outcomes in student partnerships: Partnership values in the pilot year. International Journal for Students as Partners, 1(2).

Mercer-Mapstone, L., Dvorakova, S. L., Matthews, K., Abbot, S., Cheng, B., Felten, P., Knorr, K., Marquis, E., Shammas, R., \& Swaim, K. (2017). A systematic literature review of students as partners in higher education. International Journal for Students as Partners, 1(1).

Newmann, F. M., Marks, H. M., \& Gamoran, A. (1996). Authentic pedagogy and student performance. American Journal of Education, 104(4), 280-312.

Rule, A. (2006). The components of authentic learning. Journal of Authentic Learning, 3(1), 1-10.

Schwartz, Z. (2015, October 29). Best of the best: Introducing the 2016 Maclean's university rankings. Retrieved from http://www.macleans.ca/education/best-of-the-bestintroducing-the-2016-macleans-university-rankings/ 
The Globe and Mail University Report Card. (2016). Retrieved from https://www.theglobeandmail.com/featured-reports/read-the-latest-canadianuniversity-report/article26924086/

The Huffington Post. (2017). The university hub. Retrieved from http://www.ubishops.ca/about-bu/place-among-best/

Washenko, A. (2018, April 19). Podcast consumer 2018: Share of ear doubles, smartphone dominance, and smart speaker success. Rain News. Retrieved from http://rainnews.com/podcast-consumer-2018-share-of-ear-doubles-smartphonedominance-and-smart-speaker-success/ 